\title{
Tropical War Stories: Preserving Oral Histories from World War II Borneo
}

\author{
Janet E. Marles \\ Creative Arts and Media, James Cook University, Australia
}

Maslin Bin Haji Jukim

Academy of Brunei Studies, Universiti Brunei Darussalam, Brunei

Frank Dhont

History, Universiti Brunei Darussalam, Brunei

\begin{abstract}
Traditional historical texts predominantly rely on written sources, yet oral accounts add specificity and personal depth to written narratives, particularly where written sources are sparse or unable to provide a comprehensive account of an era. This paper describes a video archive from the tropical island of Borneo. Created with graduate students from Malaysia and Brunei Darussalam across diverse language groups, this oral history project provides an archival database of first person interviews with witnesses to the Japanese occupation of Malaysian Borneo during World War II. These stories add texture and nuance to the current historical narrative, particularly for young Borneans unaware of the turbulent experiences their forebears endured during that period. The archive contributes in many unique ways to the traditional historical record and offers numerous opportunities for further research.
\end{abstract}

Keywords: Japanese Occupation, Brunei Darussalam, Borneo, World War II, Oral History, Archival Data Creation, Intergenerational Collaborative Practice

\section{Kisah-Kisah dalam kenangan (Stories through memory)}

$\mathrm{I}^{\mathrm{n}}$ magine waking one morning, taking a quick breakfast, and heading off for school as you usually do. Only on this particular morning you come upon strange men in uniform positioned around your town. You live in a small coastal community located four degrees north of the equator where most of the population reside in stilted houses above a wide river. Your tropical life-style has a distinctive routine and rhythm which has been unchanged for hundreds of years. Yet the events of this morning will completely change your life, your family members' lives and the lives of your neighbours. Your peaceful world will be turned up-side-down for four long years. 
At first sight these strange men are exciting to you. You are impressed by their formality and improbability. They appear extremely serious and many carry long swords. Immediately there is change to everyday life. The white doctor is sent away. Familiar place names are replaced with new unfamiliar names and the district boundaries are also rearranged. There is new paper-money for purchasing goods from shops, however items to buy become increasingly scarce. You continue to go to school but it is a new school and the instruction is in a new language. You learn you will be slapped if you do not obey the men in uniform and you learn to bow to them whenever they pass. You learn their songs and sing their anthem each morning as they raise their flag on the pole in your school yard.

Your older brothers and neighbours, aged 14 years and over, are taken by these men in uniform. Some are recruited to wear their uniform too. Others are used as labourers to farm and to build roads, airstrips, tunnels and ports. Your father also works for these men in uniform and some time later your father is taken prisoner by them. He is taken and interrogated. He is accused of spying. It is a very serious accusation. Many others are accused as well. It is easy for anyone to be reported. The accusers do not have to prove their claim.

You visit the prison enclosure regularly with your brother to bring your father food. On one occasion as you are leaving your father instructs you to ask the guard for some paper and a pencil. Your father writes a letter, he folds it and places it in your shirt's top pocket. As you leave, the man with the gun takes the letter and reads it. He places it back in your pocket and allows you to go. A few days later your father appears at home. There is a mad rush to get your entire family onto small boats and slip away into the deep forest.

Later you find out this getaway has been planned for some time and when the men in uniform come to recapture your father your neighbours show them a fresh grave and tell them your father has died. Your family has eluded them and you are all hiding together deep in the jungle. There is limited access to this place. You can walk or go by boat, but there is no road. You now live in a house completely made of bamboo; the pillars, walls, floor, and stairs are tied together with rattan. The roof is made of palm fronds. You get your water from the river. There is no water-pipe.

Much later you hear the uniformed men have gone and your family is able to return to their own home near the main river. A decade later your father asks you 'Do you know what I wrote on the letter?' You say you don't know. He tells you 'I wrote to your mother: They are looking after me, they know I am innocent and they will let me out soon.' You realise your father has used his wit to escape imprisonment and death at the hands of the Japanese during their occupation of your homeland in World War II.

The story above is the account provided by Pengiran Idris ${ }^{1}$ of his experiences of Japanese occupation in Brunei. It is only one of thirty-eight ${ }^{2}$ recorded interviews of survivors of World War II from Brunei Darussalam and Northern Sarawak, Malaysia on the island of Borneo.

\footnotetext{
${ }_{1}^{1}$ Pengiran Dato Haji Idris bin Pengiran Temenggung Pengiran Haji Muhammad.

2 To date 38 interviews have been conducted, transcribed and translated for this ongoing project.
} 
Collecting these, rarely disclosed, personal stories from the tropics is essential for better understanding these regions' pasts, presents and futures and aligns with the United Nations declaration of the 'International Day of the Tropics' objectives of raising awareness and empowering populations from tropical zones.

Pengiran Idris was born in Bandar Brunei in 1934. He was seven years old when the Japanese Imperial Army invaded Brunei in December 1941. They came to Borneo for resources; primarily oil, but also timber, rubber, and labour. Pengiran Idris' father worked in telecommunications for the British and when the Japanese arrived they expunged all foreigners, retaining only the local workforce. The Japanese military occupied the region until mid 1945 when, after heavy bombing by Allied Forces, Australian troops landed in Borneo. In Brunei they quickly reinstated the Sultan ${ }^{3}$ who had also escaped from the fighting by fleeing deep into the jungle. Pengiran Idris' personal narrative is one from the elite class, he was well educated and became an ambassador for Brunei serving at a number of international postings including for over a decade in Japan. He never forgot his childhood under Japanese military occupation, the punishment inflicted on his father and the hardship suffered by his extended family. He was pleased to have the opportunity to impart his experiences to the research team of international academics and graduate students from Malaysia and Brunei Darussalam (Marles \& Jukim, 2014a).

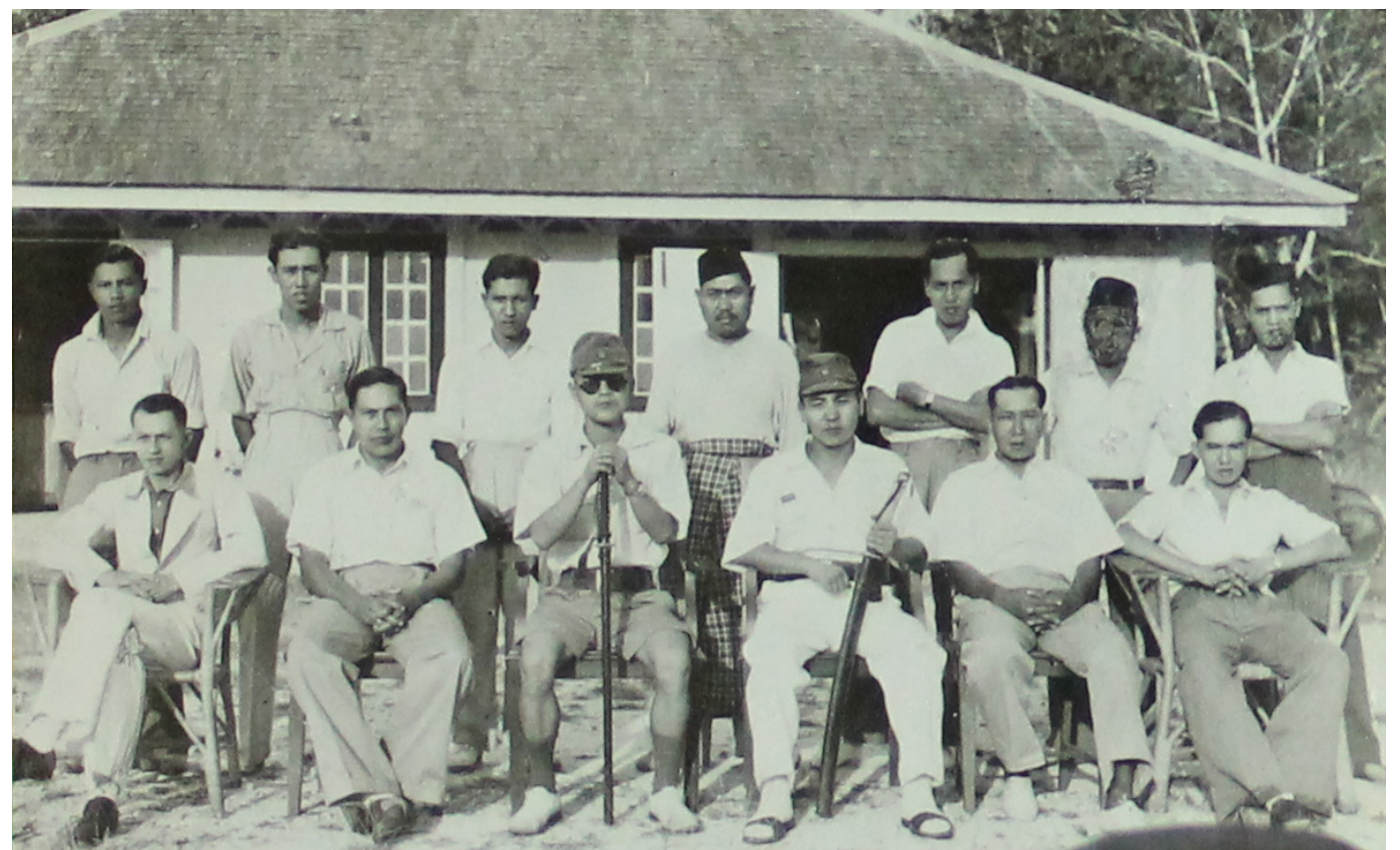

Figure 1. Pengiran Dato Haji Idris' father Pengiran Temenggung Pengiran Haji Muhammad (seated front row, second from left) in a black and white group portrait of local telecommunications workers and Japanese soldiers taken outside Brunei Telecom (circa 1942) during the Japanese occupation of Brunei in World War II.

To ensure a broad representation of people from diverse ethnic and cultural backgrounds are represented in this project, the multi-lingual research team travel widely to gather stories from both urban and remote regional areas of Brunei. Video recordings are made in the

\footnotetext{
${ }^{3}$ Sultan Sir Ahmad Tajuddin Akhazul Khairi Waddien.
} 
interviewees' mother-tongue. To date the research has seven language groups represented including Malay, Kedayan, Iban, Dusun, Murut, Hokkien and Mandarin. Once transcribed, each interview is translated into Malay and English. These two translations ensure academics and stakeholders from both English and Malay institutions and traditions can access the oral interviews and pursue further research.

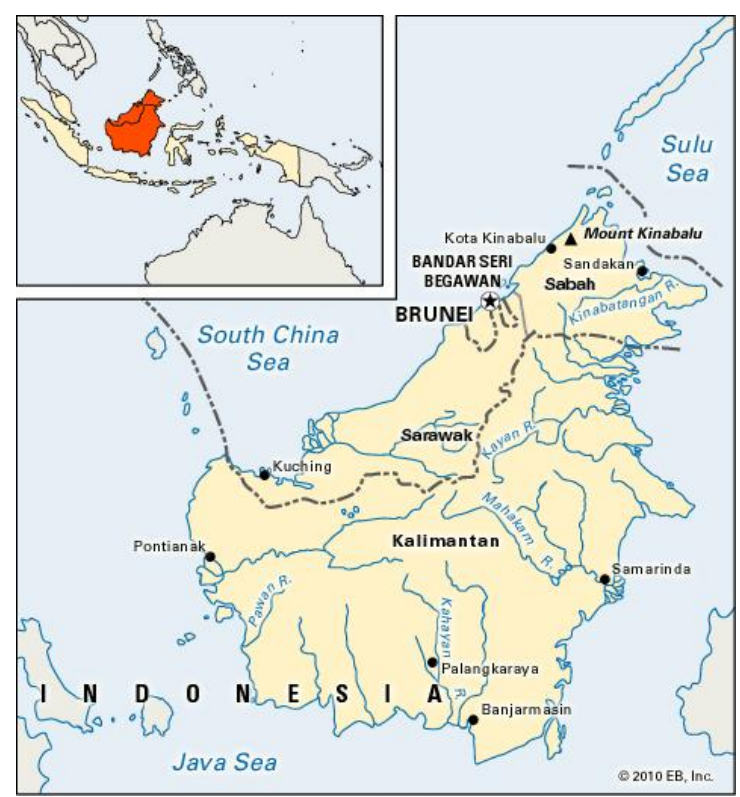

Figure 2. Map of Borneo including Sarawak and Brunei Darussalam. Encyclopaedia Britannica.

This collection of Bornean stories creates a remarkable archive that reveals the impact of the World War II occupation on predominantly ordinary people most of whom were children during this tumultuous period in their island's history. The recordings have also yielded a surprising diversity of voices and obliges the listener to be constantly aware of the element of individuality in history. Throughout this oral history experiences are commonly localised and personal. While traditional history texts offer just a few paragraphs of personal narrative, this archive offers contrasting views from diverse narrators and the viewer is able to relive each story as the witness relates it to the interviewer. Subsequent interviews offer partially, or even completely different perspectives, on similar events encouraging the viewer to compare scenarios and to contemplate why certain groups received preferential treatment while other groups were maltreated and victimized, and why this might be so. One can see how each story differs and as the stories build and intersect, how vital locality and ethnicity is to the remembered lived experiences of this time.

Another interviewee, $\mathrm{Hj}$ Matussin ${ }^{4}$ from the Tutong district, was recruited in 1942 as a twenty year-old to fight for the Japanese army. Residing in a rural area and without influential connections he chose to become a soldier because the Japanese offered him food and clothing (Marles \& Jukim, 2014b). Awang Jamit ${ }^{5}$ from the Iban community of Teraja, remembers his father and uncle helping Australian troops locate the fleeing Japanese in mid

\footnotetext{
${ }^{4}$ Haji Matussin bin Sabtu

${ }^{5}$ Awang Jamit anak Lasah
} 
1945. In Marudi, where they had been cruel to the local people, the Japanese were killed. The Iban tradition of head-hunting was revived during this period. Traditionally, taking a head was a sign of power and in some regions, the young men could not have married until they had taken a head, smoked it and hung it in their doorway. Awang Jamit says: 'they (our people) killed the ones (Japanese) who made ruckus (disturbed the locals) at the village long-houses' (Marles \& Jukim, 2014c).

Kim Choon's ${ }^{6}$ family fled Taiwan, arriving near Brunei shortly before the advancing Japanese army. Deciding the Japanese were unstoppable and likely to remain, her father chose to work with them. During the occupation young people, particularly unmarried girls, were unsafe. As a result, many young locals married their cousin as a means to protect single girls from the Japanese. Kim Choon says she did not have to marry because her father worked with the Japanese. 'They said to my father, if anyone bothers you, let us know' (Marles \& Jukim, 2014d).

\section{Background and methodology}

This oral history research originates from Universiti Brunei Darussalam research grants of 2013 to 2016 and focuses, where possible, on interviews with people who witnessed the Japanese occupation of Brunei and Northern Sarawak (1941-1945). One primary objective is to explore the historical period during World War II and ensure young generations of Bruneians and Malaysians understand life as it was lived in Borneo during the Japanese occupation. From the interviews, the research discovers not only the experience of ordinary Borneans during the Japanese administration, but we also gain a glimpse into life before 1941, prior to the invasion of the Japanese Imperial Army. We obtain insights into: what traditions and values were upheld, how food was acquired and processed, how people worked and traveled, how they related to one another, and the clothing and shoes they wore. Most interviewees were aged between ten and twenty-four years during the war period. Now over eighty years of age these survivors live today, as in earlier times, mostly with their extended family.

During the war period, ethic communities were remote and isolated. There were few roads. Traveling more than a small distance was limited to boat access. The major rivers were the highways with regions and localities even more distinct and unique than they are today. Consequently, people from inland and inaccessible areas experienced the Japanese occupation quite differently from those located in coastal regions or those near the larger townships like Bandar Brunei or Miri. To date the research has conducted interviews throughout seven districts of East Malaysia and Brunei Darussalam: Labuan, Telahak, Limbang, Belait, Tutong, Muara Bandar, Temburong.

Added to this unique archive of Bornean stories are the memories of the Allied troops, primarily Australian men, who served in Borneo in the mid 1940s. In June 2015 during the

\footnotetext{
${ }^{6}$ Madame Pong Kim Choon.
} 
commemoration of the 70th Anniversary of the Borneo campaigns of World War II led by Australian forces the research team was able to video record interviews with two Australian World War II veterans who landed at Muara on 10th June 1945; Mr. Jack Olsson OAM, and Mr. Brian Wearne. Following Charles T. Morrisey's experience interviewing US Presidents, (cited in Thomson 1999, p. 82) the interviews were 'flexible and mutable' and acknowledged the formula for successful oral history recording: forethought and preparation, establishment of rapport and intimacy with interviewees, listening carefully, asking only open-ended questions, not interrupting, allowing the interviewee pauses and silences, avoiding jargon and probing, and, where possible, minimising the presence of the recording equipment.

Once a potential interviewee was identified a preliminary interview would establish contact between their family and the interview team of academics and graduate students. The preliminary interview ensures the health of the interviewee as well as their willingness to have their story recorded. The team began with their extended family or neighbours. In this way it was easier to establish a good rapport and connection with octogenarian uncles, aunts, grandfathers, grandmothers and neighbours. Mindful of the strangeness of the request and the intrusion this could cause to the interviewee and their family the research team scheduled interviews at times and places that suited the participants. In Brunei Darussalam Friday and Sunday are good days for conducting interviews with elderly Bruneians in their home environment surrounded by their close relatives, which ensures they feel more comfortable with the imposition of an interview team. Friday and Sundays are both public holidays and culturally both days are spent fulfilling family obligations including attending social occasions such as wedding ceremonies.

For this research approach to be successful the culture and tradition of the Bornean people must also be understood and respected. Bruneians are generally very cautious and tend to reject invitations to speak in order to avoid conflict. They are likely to say 'I am sorry I don't know much...' when actually they know quite a lot. In these circumstances the interviewers need the knowledge and skill to gently break through their reticence. It could well be that the octogenarian Bruneian's reluctance to speak stems from two traumatic upheavals during their lives, first this generation witnessed the hardship of the Japanese occupation of Brunei from 1941-1945 and some are still fearful to speak openly about this period in their lives. Secondly, as adults in the early 1960s, this demographic also lived through the turbulence of the Rebellion incident or Pemberontakan Brunei. Seen as one of the first stages of the Indonesia-Malaysia Konfrontasi the Brunei revolt of December 1962 was an unsuccessful attempt by those opposed to the monarchy and the proposed union with Malaysia to form the North Borneo Federation with Indonesia. The choice of starting the interviews with family members is critical for the success of the research, and in conjunction with showcasing exhibitions and seminars, has enabled the spread of knowledge and ideals of the project to interviewee's relatives, neighbours, friends, and associates.

Another challenge of video recording oral history interviews is the intimidating appearance of the technical video equipment. Some interviewees were daunted by the presence of the recording equipment and became self-conscious and too shy to speak. In such cases a 
family-psychological approach played an important role. The team worked with the help of family members to build up the interviewee's confidence and willingness to be a participant in the project. Strategies for relaxing the interviewee were used sometimes by discussing other subjects and setting up the equipment elsewhere. With these efforts and the help of the family members the video recordings of the interviews were largely smooth and successful. In some cases, once the family observed the interview process, additional family members chose to come forward to be interviewed for the project. Some interviewees responded positively to the project and understood the importance of creating an archive for future generations. Many provided copies of their own personal photographs for the project. Others asked for a second interview, as the first interview had stimulated their recall and they had further details to convey to the team.

Often this was the first occasion interviewees had been invited to speak about their experiences as children under Japanese occupation. Following McNally's (2003, p. 48-63) findings from the numerous studies he reviewed on traumatic memory, there are six elements at work enabling stressful memories to be encoded strongly: emotional arousal while encoding; distinctiveness of the event; degree of surprise experienced; perceived personal relevance; directly experiencing the event; and rehearsal of the reception context. The perceived importance of an event combined with the degree of surprise determines the emotional intensity of the response. The more emotion experienced the more likely the person will revisit the memory - the process of rehearsal - which in turn, strengthens the memory for the event. In addition, both directly experiencing the event and its distinctiveness ensures that the memory is tagged as a unique experience warranting special processing. Their experiences of Japanese occupation were laid down in the interviewee's long-term memory under extreme conditions of heightened personal emotions. The period of occupation was long enough to be significant, yet life returned to its usual routine soon after the Japanese defeat. This made the Japanese occupation a unique and distinctive event in the interviewees lives enabling their recollections from childhood to remain strong, vivid memories that are 'surprisingly accurate'.

\section{Intergenerational understanding}

Following the initial interviews conducted by Janet Marles, fifteen graduate students from Malaysia and the Universiti Brunei Darussalam have been engaged with the project according to their technical and language skills. Selected students are taught to operate a high definition video camera and also the production techniques and work-flow for interviewbased documentary production. Maintaining high quality vision and audio for the interviews requires additional time and effort by the research team in video-capture and editing, however the overwhelmingly positive response from audiences at exhibition and seminars showcases indicates that this has been beneficial. From April 2014 to November 2015 this research has been exhibited five times throughout Brunei Darussalam. In June 2015 the exhibition ran for one month and received over 1000 visitors; a huge response from the small community of 50,000 people of Bandar Seri Begawan. This showcase was so successful that the exhibition was invited to tour the regional districts of Belait, Tutong and Temburong in November 2015. 
In 2016 a series of school visits brought the research to secondary students in the Brunei Muara district.

Positioned in their home environment the interviewee describes events as we, the audience, observe their body language - their physical and emotional reactions as they recall their stories. The pauses, the nuance, the tone, the hesitance, the excitement, the humour and the horror are visualised, bringing us closer to the story-teller and their lived experience. This elevates the interviews above the written transcript and reduces the 'mediating role of the interviewer' as described by Dan Sipe in Thomson (1999, p. 88). Graduate students establish initial contact with interviewees within their ethnic group ${ }^{7}$. As outlined above, their extended family networks provide unique access and give breadth and diversity to the selection of interviewees. The students conduct preliminary interviews and establish informed-consent for video recording. Speaking in their 'mother tongue' was essential in most instances and also for transcription and translation of the final recorded interviews.

After each interview the students regularly express surprise at the content of the stories; that their elders endured such hardship, that they have never heard these events before (from their elders or from their history books), that this research encourages them to explore further the untold histories around them. They gain awareness for the stories themselves as well as a new appreciation for their elders who lived through the events of World War II. When describing their astonishment, the students used words such as 'gift' and 'eye-opening' and remain enthusiastic in pursuing the research and following up with further interviews. All have had remarkable thought-provoking experiences. Graduate student Izzati Nordin, for example, said:

I've studied history for almost five years and these stories are also new to me, these stories weren't in the textbooks. This project has opened my eyes to what the people of Brunei have gone through and what more can be learned about the people of Brunei (Marles \& Jukim, 2014e).

Another example comes from graduate student Chin Siew Yee (Sally). Sally identifies as Chinese, is fluent in Mandarin and English and also speaks some Malay, yet her maternal grandmother Mayan Binti Umang is Dusun, from the Tutong District. Growing up immersed in different languages and cultures grandmother and granddaughter were unable to speak together. Sally says:

I was never very close to my Grandmother and thanks to this research project I got to know my Grandma better on a different level...and this project taught us... he interviewers, to give better respect (to the elders) and a memory that we can keep for the next generations; it's a gift for us as well as a preservation (Marles \& Jukim, 2014f).

The awareness and respect for the life experiences of close family goes both ways. While sometimes a little daunted by the technology, the interviewed elders are impressed by their grandchildren's ability to manage the complex and technical equipment as well as

\footnotetext{
${ }^{7}$ Malay, Dusun, Iban, Kedayan, Murut, Chinese (Hokkien, Mandarin)
} 
the intricate workflow employed by the project.

\section{Work-flow}

The workflow for each interview is comprehensively standardised. As stated above, a preliminary interview establishes contact, explains the overarching aims of the project, and obtains initial informed-consent for video recording with the proposed interviewee. Once agreement had been reached a time is set to bring the research team together for conducting the video-recorded interview. Usually, three team members attend the interview - the interviewer, the videographer and the translator. Typically, interviews are conducted in the interviewee's home and last approximately one hour. Including travel and set-up time, it is only possible to conduct a maximum of four interviews per day. The Sony XDcam ${ }^{\circledR}$ highdefinition video camera provides broadcast quality footage and is able to cope with low-light interiors. A lapel microphone is used to ensure the highest quality audio recording for the interviewee's voice. If possible, a second camera records a B-roll. Still photographs are also taken for use in print media and promotions. Two consent forms are signed on conclusion of the interview. The interviewee (or their representative) retains one copy and the other copy is filed with the research team.

As a token of our appreciation for their cooperation, a framed portrait of the interviewee is given to the interviewee (or their family) along with a certificate of appreciation and a poster compilation used to publicize the showcase exhibitions. Funding is only available to pay graduate students for translations, videography and editing. It is not possible to pay the interviewees. Consequently, some potential participants are lost, but lack of payment also ensures the research does not record people 'creating' stories for 'sale'. In this way the research team can be reasonably certain the collected stories are not invented for fame or fortune.

The recorded video files are duplicated and the catalogued files are stored in an online archive which can be added to and accessed by international members of the team. Each raw video interview is commonly between 15-20 gigabytes and approximately one hour in duration. The unedited raw interview is transcribed into the original spoken language (where possible) and translated into English and Malay. Each raw one-hour video is edited into a three-minute condensed 'story video' with the interviewee speaking their mother tongue with English subtitles.

In addition to the individual edited three-minute interview videos, ten themed-videos thread together sections of the interviews that complement each other. These themed videos create a timeline that charts the chronology of the war: Japanese Arrival; Changes to Work; Japanese Schooling; Shortages; A Father's Letter; Hard Times; Starvation; Locals Fleeing; Japanese Evacuating; Locals Returning Home. Viewed together the themed videos provide a sequential timeline for the Japanese occupation with a combined duration of forty-five minutes. Additionally, a 'Behind the Scenes' video reveals the experiences and challenges faced by the graduate students involved in the project and a thirty second introductory 
compilation video imparts the essence of the project.

\section{Outreach}

The edited videos have been shown to audiences in exhibitions throughout Brunei Darussalam, initially in April 2014 as a showcase at Universiti Brunei Darussalam and again in June 2015 to commemorate the $70^{\text {th }}$ anniversary of Australian Forces arriving in Brunei at the end of World War II in collaboration with the Australian High Commission to Brunei Darussalam, Australian Department of Veterans Affairs, Brunei Museums, Universiti Brunei Darussalam and James Cook University. This anniversary exhibition included black and white historical photographs sourced from the Australian War Memorial (AWM) photographic collection and was so popular with the local people it was consigned to tour, for the month of November 2015, to the regional districts of Brunei Darussalam.

An unexpected outcome of the touring exhibition was the identification of some of the local people in the historical black and white images provided by the Australian War Memorial photographic collection. One image of Australian soldiers sitting either side of a Malay man is captioned:

Brunei, North Borneo. 13 June 1945. Private B G Simmonds (2) and Pte A G McDonald (2) members of 2/17 infantry battalion, speaking to a Malay in the Foochow area, during the unit Oboe 6 operation advance (Australian War Memorial, 1945a).

Members of the exhibition public identified the Malay man in this photograph as their greatgrand father. The archive now has the name Haji Jamudin (Zamudin) bin Omar Ali for the 'Malay' to add to the photo caption and the historical record.

Another image of Sultan Sir Ahmad Tajuddin Akhazul Khairi Waddien and his wife Tengku Raihani returning to Bandar Brunei by boat shows a number of Malay men accompanying the Sultan. Captioned:

Brunei, North Borneo. 17 June 1945. Native prau (boat) bearing, The Sultan of Brunei, his wife and party, moving towards the wharf after their journey from the village of Tentayer, whence they fled during the bombing of Brunei (Australian War Memorial, 1945b).

Some of the men described as 'party' have also been identified by our research student Aqilah Makhbah's family. Her grandfather, $\mathrm{Hj}$ Moktal, is the man paddling the Sultan's boat from the front. $\mathrm{He}$ is wearing the saraung laki (traditional Bruneian hat). $\mathrm{Hj} \mathrm{Chu} \mathrm{Chu}$ bin Ismail sits behind him. He is also paddling and wears a songkok (black cap). Further back and turning to look at the Sultan is Hj Putting bin Ahmad. He wears a tengkuluk (head covering).

\section{Linguistic challenges}

In addition to identifying some of the local people pictured in the historical collection of the Australian War Memorial this oral history work encountered a number of interesting linguistic challenges. One example was an interviewee who spoke Hokkien, Mandarin and Malay. This 
interviewee switched between these three languages as he spoke, depending on who he was looking at while speaking. If his eye caught a Chinese crew member he spoke Mandarin, as his glance moved to a Malay crew member he switched to Malay and in between he used many Hokkien references. This particular interview required three translations; one for Malay, another for Mandarin and yet another for Hokkien. We discovered that the young generation of Chinese in Brunei Darussalam commonly speak Mandarin, Malay and English but few speak Hokkien so this interview had to be translated by a Chinese student from Penang, Malaysia where Hokkien is still widely spoken and understood.

Another example came from the interview with an elder from Kasat district who described his families' lack of basic essentials and their need to use mosquito nets for clothing during the Japanese occupation. This interviewee used an old Bruneian term for 'bug droppings' which was not known to the younger Bruneian translator. When our Malay language expert Maslin Jukim reviewed the transcript he was able to identify the error and correct it. As with all languages Bruneian Malay evolves over time and certain slang words used by the older generation lose their regular usage and prominence resulting in the younger generation of Malay speaking Bruneians becoming unfamiliar with such terms.

\section{Hindsight}

Pengiran Idris ${ }^{\prime 8}$ story of his father's letter sent from prison, recounted at the start of this paper, touches on personal as well as political aspects of the Japanese occupation period. $\mathrm{He}$ explains there were two types of Japanese; those that ran the government, and the soldiers. The soldiers were the cruel ones. The government workers were just like anyone else. 'They were nice to children' (Marles \& Jukim, 2014a). He also poses a succinct challenge to the claim asserted by the Japanese for the invasion of Asia (including Brunei) during World War II as liberating the locals from European colonisation when he says:

Well as hindsight, the Japanese came here; this is what they're saying later. That they're going to liberate us in Brunei, or all this part of the world in Southeast Asia. To liberate these countries from being a colony of the British. But once they get rid of the British, why stay here for four years? That is one big question mark. If they really said that they want to liberate us, why stay for four years and why keep soldiers here for that period and frightening the inhabitants of the country. That's one big question mark to me (Marles \& Jukim, 2014a).

\section{Conclusion}

This paper outlines the processes, challenges and achievements of recording an oral history archive of witnesses to World War II in Northern Sarawak, Malaysia and Brunei Darussalam on the tropical island of Borneo. It describes a valuable collection of interviews with elderly men and women from diverse language and ethnic backgrounds, each with a unique perspective on life and survival under Japanese occupation. The element of individuality makes this project intense, with each remembered story introducing a new world. The contextual differences in each interviewee's life circumstances make these events direct and

\footnotetext{
${ }^{8}$ Pengiran Dato Haji Idris bin Pengiran Temenggung Pengiran Haji Muhammad.
} 
personal for the viewer.

There is value too in creating such an archive as a learning experience for young Malaysians and Bruneians who are becoming increasingly curious about their roots and who are interested in sharing gleaned knowledge with their communities. This is one of the most important aspects of this collection of thirty-eight distinctive narratives, all equally important and unique, and all worthy of engagement and further investigation. These tropical stories are time sensitive and each year a few more slip through the net of our collective memory. Just as the United Nations declaration of the 'International Day of the Tropics' was created to celebrate the experiences and voices of the peoples and places of tropical regions, so too the tropical war stories oral history archive from World War II Borneo contributes towards this endeavor of engaging with and within the tropics with a new 'tropics lens'. 


\section{References}

Australian War Memorial (1945a). Photographs Collection, File No. 109297.

Australian War Memorial (1945b). Photographs Collection, File No. 109542.

Marles, J.E., \& Jukim, M. (2014a, March, 15). Interview by Afiqah Ibnu [Video file no. Bl12_MANG]. Stories Through Memories: Universiti Brunei Darussalam. James Cook University Archives, Australia.

Marles, J.E., \& Jukim, M. (2014b, January, 11). Interview by N. Faiqah Hamdan [Video file no. BI04_TUTO]. Stories Through Memories, Universiti Brunei Darussalam. James Cook University Archives (JCU-HPRC), Australia.

Marles, J.E., \& Jukim, M. (2014c, February, 24). Interview by Izzati Nordin [Video file no. BI09_TERA]. Stories Through Memories, Universiti Brunei Darussalam. James Cook University Archives (JCU-HPRC), Australia.

Marles, J.E., \& Jukim, M. (2014d, January, 19). Interview by Chin Siew Yee, Sally [Video file no. BI03_MUAR]. Stories Through Memories, Universiti Brunei Darussalam. James Cook University Archives (JCU-HPRC), Australia.

Marles, J.E., \& Jukim, M. (2014e, May 4). Interview by Janet E. Marles [Video file no. BTS_BI_SI_04]. Stories Through Memories Project: Universiti Brunei Darussalam. James Cook University Archives (JCU-HPRC), Australia.

Marles, J.E., \& Jukim, M. (2014f, May 4). Interview by Janet E. Marles [Video file no. BTS_BI_SI_02]. Stories Through Memories, Universiti Brunei Darussalam. James Cook University Archives (JCU-HPRC), Australia.

McNally, R.J. (2003) Remembering trauma. Cambridge, MA: Belknap of Harvard University Press. Thomson, A. (1999). Fifty years on: An international perspective on oral history. Oral History Association of Australia Journal, 21, 82-91. 